\title{
DEVELOPMENT OF PROCEDURES OF DETERMINING THE FINANCIAL RESULT BASED ON DATINI'S FIRST PROPRIETORSHIP
}

\begin{abstract}
This paper studies the accounting system of Francesco Datini's first proprietorship in Pisa (1383-1406) which was marked accounts for Merchandise ("Purchase and Sale of Goods") and accounts for accumulating the financial result. The first group of accounts was opened for each batch of goods sold. These accounts revealed the financial result after the sale of a batch of goods. The result from the Merchandise account was transferred to accounts for accumulating the financial result. All the conditions for the preparation of the "Profit on Merchandise" ("Profit on merchandise" account) were present in this accounting system. In the first proprietorship, such an account was not produced until 1406. However, from the middle of 1386 new purchases in the first proprietorship were not made and the Merchandise ("Purchase and Sale of Goods") accounts were not opened. However, personal debtor accounts — the buyers of earlier purchased goods — were regularly opened.
\end{abstract}

Key words: Proprietorships, Medieval accounting, determination of financial result

\section{INTRODUCTION}

Francesco di Marco Datini (c.1335-1410) was head of a large trading network that operated in Avignon, Pisa, Florence, Prato, Genoa, Barcelona, Valencia and Majorca between 1363 and his death in 1410. Datini made connections and acted, through correspondents, representatives and successors, in numerous markets and production centres in Italy, France, Spain, North Africa, Flanders and England (Cecchi, 2004; de Roover, 1956). His business started in Avignon, during the period of the Avignon Papacy. In 1382, he returned to Prato and opened his central trading enterprise and other proprietorships and companies in other cities, included the proprietorship in Pisa in that year.

Datini managed this huge trade network personally and supervised the activity of every enterprise through business correspondence and requiring regular reports from his partners and agents in a balance account form. A large number of different business documents (correspondence letters, insurance policies, bills of exchange, etc) and approximately 500 account books have been preserved in Prato and kept now in the State Archive of Prato. These documents, account books and records form the primary source for this study.

There is a perception that preserved medieval archival materials, i.e. the books that comprise the accounting records of these companies, dating back to 14th-15th centuries, has already been extensively investigated by researchers and representatives of different schools of thought. When applied to the Datini companies, as well as in general to the development of double-entry bookkeeping, various influential factors have been cited, starting with the simplest internal ones in the form of increasing the professional skills of an accountant or with the appearance of accounts with parallel debit and credit sides (bilateral). The first detailed studies dedicated to formal attributes of doubleentry bookkeeping were carried out by F. Besta (1909, 342), A. Littleton (1966, 12-21). Further, this research sphere was developed by de Roover $(1937,274-275 ; 1956,141)$, T. Zerbi $(1936 ; 1952,131-$ 136), and F. Melis (1950). Modern researchers in the history of accounting also should be mentioned (Antonelli, 2012; Sargiacomo, 2012; Sangster, 2016).

These authors emphasized the role of revenues and expenditures as the factors directly influencing the financial result, and focused on the special accounts created for recording these elements.

The present paper aims to trace the development of the stages of the procedure for determining the financial result and the identification of the factors that have an impact on the development of the accounting system.

The primary contribution of this paper lies in its finding that while Melis (Melis, 1950, pp. $176-$ 177) has indicated that the first Datini's proprietorship was officially closed on August 19, 1386, the 
account "Profit on Merchandise" (a forerunner of the profit and loss account) for the first proprietorship 
was not prepared until 1406. This finding shows that the account books for the first proprietorship remained open until all of the goods purchased by that proprietorship were sold. Melis incorrectly assumed that because the second partnership was opened on August 20, 1386, that this meant that the first proprietorship was closed. However, personal accounts in the Ledger for the first proprietorship were opened in subsequent years, thus indicating that the accounts of the first proprietorship remained open. Moreover, while all the accounts in the 'Mercanzie' were dated 1384-1386, the final accounting for the first partnership was not completed until 1406.

The second contribution of this paper is that it provides details of features about medieval techniques of determining the financial result in the accounting records.

\section{Prior literature ON MEDIEVAL FINANCIAL RESUlt ACCOUNTING}

Referring to the causes and places of the emergence of double-entry bookkeeping A. Martinelli concluded:

“...the person who undertakes research on the origination of double entry bookkeeping through medieval ledgers must be mainly concerned with tracing the first appearance of derived or income accounts of profits and losses which have been essentially instrumental to attain the constant debit and credit duplication of entries" (Martinelli, 1974, p. 291).

Many scholars have mentioned trading transactions and the determination of financial results in the accounts in different medieval companies in their research describing the account books where the Merchandise accounts and the Profits and Loss accounts are present. Many of these researchers provide examples of these accounts.

G.A. Lee (Lee, 1973) studied the development of Italian Bookkeeping 1211-1300. He took a comprehensive view of Italian (especially Tuscan) bookkeeping in the thirteenth century, and endeavored to trace the lines of evolution from the surprisingly sophisticated ledger of 1211 to the emergence of double-entry, or approximations to it, around 1300. Considerable attention has been paid to reflecting of interest (guadagno), profit (avanzo) and loss (disavanzo). He described examples from the account books Gentile de' Sassetti \& Sons (1274-1310), Bene Bencivenni (second ledger) (127796), Filippo Peruzzi \& Co (1292-93).

In another paper (Lee, 1977) described the accounting system of Giovanni Farolfi's branch in Salon (1299-1300) and special attention was paid to the procedure of reflection of transaction in the Merchandise account and determination of financial result.

The book of Massari of Genoa (1340), which for a long time was believed to be the earliest accounting book where double entry was used (Besta, 1909, p. 273), shows how the financial result was determined at that time and how it was appropriate for a commune. The income was accounted by the cash method, i.e., at the time of receiving the money, and expenses were accounted by the accrual concept (expenses were accounted for at the time of occurrence instead of payment) (Kuter, 2013). The account of the Commune of Genoa which functioned as a capital account to which the balances of all expense and revenue accounts were transferred when the books were closed at the end of the fiscal year, was investigated by many accounting historians (de Roover, 1956; Martinelli, 1974; and etc.).

R. de Roover described the activities of many early medieval companies, mentioning some features of determination of financial result in the accounting books (de Roover, 1956) which is the subject of our research.

With regard to the business activity of Francesco di Marco Datini, the first referencesto his proprietorships and companies are to be found in the works of Fabio Besta (Besta, 1909, 317-320) and his students such as Corsani (Corsani, 1922, 83-85) and Alberto Ceccherelli (1913; 1914a; 1914b; 1939).

Some authors of the first half of the $20^{\text {th }}$ century (Melis (1954); Carradori (1896); Livi (1910); Nicastro (1914); and Bensa $(1923 ; 1925 ; 1928))$ described the account books stored in the State 
Archive of Prato, the city where Datini lived and worked. However, none of these previous researchers focused attention on the manner in which the medieval accountant maintained various accounting procedures, or in which accounts he reflected various transactions. The aforementioned archival researchers did not place an emphasis on discussing double-entry or any accounting procedures based upon it, which already existed in the Middle Ages.

F. Melis, R.de Roover, T. Zerbi, A. Martinelli can be included among the researchers who studied Datini during the second half of the past century. Melis dedicated a great deal of time exploring the account books in the archive of Prato. Even the page numbering of those books belongs to his hand. F. Melis has done a great deal of work in matching the books according to the companies to which they related (Melis, 1962). However, Melis, who also studied materials from other archives (Melis, 1950, 1972), paid attention to the Datini materials in only one of his works (1954), published in Italian and English.

Therefore, although much has been written about Datini, his business and his archives (e.g. Origo, 1958; Nigro, 2010), little has been written about Datini's accounting practices.

The subject of our research - the accounting system of the first proprietorship of Francesco Datini in Pisa was previously mentioned by F. Besta:
"Questo libro Grande Giallo B cominciato l'anno 1383, il piu antico della raccolta Datini che contega conti a sezioni divise lateralmente, non e tutto compiutamente a partita doppia; vi sono a sezioni divise lateramente soltanto I conti ai debitori e ai creditori: a carte CCCXXCVIIII han principio conti a utili e danni, a mercanzie, a masserita, ecc., che sono a sezioni sovrapposte" (Besta, 1909, p 319).

Subsequently, R. de Roover, in his chapter "The Development of Accounting Prior to Luca Pacioli According to the Account-books of Medieval Merchants" in "Studies in the History of Accounting" by A.C. Littleton and B.S. Yamey B.S. wrote about the structure of accounts in the Datini's companies:
"This system is altered in a later ledger (1383-1386), also a Libro Giallo, belonging to Datini's Pisan branch. In it, the personal accounts for receivables and payables are in bilateral form, but merchandise expense and profit-and-loss accounts continue to have the credit beneath instead of beside the debit. The presence of accounts for operating results have led to the conclusion that this ledger is in double entry" (de Roover, 1956, p. 141).

Despite the fact that these scholars mentioned only one book of the accounting system of the first proprietorship, we can continue the study the procedure of determination of financial results using archival material, belonging to Datini.

The review of the descriptions of the Datini accounting systems indicates that the archival materials were probably not thoroughly studied; many practices of various accounting procedures are still not sufficiently understood. Prior authors have not distinguished the principles of system development. The basis of our research lies in the linkage of objectives, purposes, and structure of the accounts for the determination of the financial result.

\section{RESEARCH METHOD}

The principal research method adopted in this study is archival. It uses material found in the State Archive of Prato. This research team has been working with the material in this archive for the past decade and many of the records have been recorded and linked together using logical-analytical modelling. This is an approach that we developed for the purpose of enabling entries in the account

\footnotetext{
1 This Ledger Yellow B began in 1383, the oldest of the Datini collection that includes accounts with sections divided sideways, and not all completely double entry; there are sections divided sideways with only accounts to debtors and creditors: cards CCCXXCVIIII have principal accounts for profits and losses, merchandise, utensils etc., which are overlapping sections.
} 
books to be traced visually between accounts and books and from page to page. By adopting this approach, we are able to see the entire accounting system electronically, making entries and their sources clear in a way that is not possible if all that you have is the original set of account books. This enables us to consider each transaction in detail, trace its classification, and so explain the bookkeeping and accounting methods adopted without misinterpretation. This approach represents a new paradigm in how to analyze and interpret accounting practices for periods when there was no concept of either a standard method or a unified approach to either financial recording or financial reporting. In this paper, we present the bookkeeping method adopted by the accountant in Pisa. As far as we are aware, the entries in the account books included in this study have never previously been analyzed.

\section{THE PROPRIETORSHIPS AND COMPANIES OF FRANCESCO DI MARCO DATINI IN PISA}

Along with any emotional considerations which may have prompted Francesco Datini, after setting up his Avignon company, to think of Tuscany next as his s center of trading operations, was profit related. He developed the idea of opening a business in Pisa when he was in Avignon. Despite some his friends discouraging him, Porto Pisano (the port for Pisa) was a very important commercial center, located on both a two rivers route and an overlanded route (Nigro, 2010, p. 281-320).

The beginning of trading activity according the records in accounting books for the first Pisa proprietorship was the 1st of November of 1382. However, the official presentation of the first Datini proprietorship was the 5th of February of 1383. The activity of Datini in Pisa continued till his death in 1410. As claimed by Federigo Melis (Melis, 1962), Datini re-opened his business in Pisa eight times. Twice, from 1383 until 1392 there were sole proprietorships and from 1392 until 1400 there were six companies where his partner was Manno D'albizo Degli Agli. During the period until 1410 there was a procedure of liquidation of the company. As a whole, the period of Datini's business in Pisa continued for 28 years and 2 months. The requirement for a distribution the profit existed only after the closing of company.

The main interest of this study is the accounting system and the procedure of determination of financial result in the first proprietorship in Pisa.

\section{THE SYSTEM OF ACCOUNTING REGISTERS AND ACCOUNTS RELATED T THE DETERMINATION OF FINANCIAL RESULT}

The organization of accounting in the enterprises of Francesco di Marco Datini provided for opening of a certain set of accounting books for every period of its activity. The set of books usually included: Memoriale - special book for system and non-system entries; Mercanzie - Merchandize book; Entrata e Uscita - special book for money accounting; Libro Grande - the main book of the accounting system (Ledger). At the same time other books were used -Quaderni (Quaderni for money accounting, merchandize accounting and other).

To reflect the transactions during the period of activity of the first proprietorship the following account books were opened:

Memoriale A (1383 - 1383) - Prato, As, D. №366

Memoriale Bianco B (1383 - 1385) - Prato, As, D. №367

Memoriale C (1385 - 1387 (1406)) - Prato, As, D. №368

Libro Di Mercanzie (1384 - 1386 (1406)) - Prato, As, D. №377

Entrata E Uscita A (1383 - 1383) - Prato, As, D. №423

Entrata E Uscita (1383 - 1386) - Prato, As, D. №403

Libro Grande Giallo B (1383 - 1408) - Prato, As, D. №357.

In Avignon, where F. Datini's companies and proprietorships used single entry accounting to determining the financial result, the accountant could show the financial result as a whole, calculated by means of inventory and assessment of property, capital, active and passive debt obligations (Kuter, 
2020). The double entry in Pisa made it possible to track the accounting procedure. A well-established mechanism for deriving financial results was based on a competent organization of accounting in the accounting registers.

For these purposes the following Merchandise accounts were used:

- "Purchase and Sale of goods" accounts intended to determine the transaction result for a batch of goods;

- the accounts for operational results accumulation: separate accounts for accumulated profits and separate accounts for accumulated losses from trades and other activities (R. de Roover called them "accounts for operating results");

- "Profit on Merchandise" ("Profit on merchandise" account, a forerunner of the profit and loss account), designed to determine the financial result over all types of activities.

One of the aims of this paper is to identify the stages in the of the procedure for determining the financial result and the influencing factors. To do so, Table 1 examines the structure of the archive labelled "Prato, AS. D., №357" - the General Ledger of the first proprietorship of F. Datini in Pisa, opened in 1383. In this case, one can agree with de Roover $(1956,141)$, who claimed that in Pisa (1383) in the General Ledger (Campione Giallo (B) - Prato, AS, D. №357) the debtors and creditors accounts were opened in the Venetian form (De Roover, 1956, 141), In addition to the personal (settlement) accounts, it contained the Merchandise account to reflect Purchase and Sale of Goods and the accounts for the accumulation of the operational results (operating profits and operating losses separately according to the types of activities).

Table 1. The structure of the archive "Prato, AS. D., №357”

\begin{tabular}{|c|c|c|c|c|c|c|c|c|}
\hline \multicolumn{9}{|c|}{ Personal (transaction) accounts } \\
\hline 1383 & 1384 & 1385 & \multicolumn{2}{|c|}{1386} & \multicolumn{2}{|l|}{1387} & 1403 & 1406 \\
\hline $2 \mathrm{v}-110 \mathrm{r}$ & $110 v-255 r$ & $\begin{array}{l}255 \mathrm{v}-329 \mathrm{r} \\
401 \mathrm{v}-425 \mathrm{r}\end{array}$ & \multicolumn{2}{|c|}{$425 v-459 r$} & \multicolumn{2}{|c|}{$459 v-462 \mathrm{r}$} & $462 v-465 r$ & $465 v-468 r$ \\
\hline \multicolumn{9}{|c|}{ Merchandise Accounts (Purchase and Sale of goods) } \\
\hline \multicolumn{2}{|c|}{$1382(9-25)$} & \multicolumn{3}{|c|}{$1383(67-141)$} & \multicolumn{4}{|c|}{$1384(35-73)$} \\
\hline \multicolumn{2}{|c|}{$340 r-344 r$} & \multicolumn{3}{|c|}{$\begin{array}{c}331 \mathrm{v}, 332 \mathrm{v}, 335 \mathrm{r}(1), 336 \mathrm{r} \\
344 \mathrm{v}-375 \mathrm{v}\end{array}$} & \multicolumn{4}{|c|}{$\begin{array}{c}376 \mathrm{r}-379 \mathrm{v}, 380 \mathrm{v}-381 \mathrm{r}, 382 \mathrm{r}, 383 \mathrm{r}-389 \mathrm{v} \\
395 \mathrm{r}-397 \mathrm{v}, 398 \mathrm{v}-400 \mathrm{v}\end{array}$} \\
\hline \multicolumn{9}{|c|}{ Profit and Losses of trading activities } \\
\hline \multirow{2}{*}{ Year } & \multicolumn{5}{|c|}{ Accumulating operational accounts for profits } & \multicolumn{3}{|c|}{$\begin{array}{c}\text { Accumulating operational accounts for } \\
\text { losses }\end{array}$} \\
\hline & P1.1 (5) & \multicolumn{2}{|c|}{$\mathrm{P} 1.2(4)$} & \multicolumn{2}{|c|}{$\mathrm{P} 1.4(11)$} & & $\mathrm{L} 1.1$ (1) & $\mathrm{L} 1.2(2)$ \\
\hline $\begin{array}{l}1383 \\
(12)\end{array}$ & $\begin{array}{c}330 \mathrm{v}, 335 \mathrm{r}(2), \\
338 \mathrm{v}\end{array}$ & \multicolumn{2}{|c|}{$330 \mathrm{r}, 335 \mathrm{v}, 338 \mathrm{r}$} & \multicolumn{2}{|c|}{$\begin{array}{c}333 \mathrm{v}, 334 \mathrm{v}, 336 \mathrm{v}, \\
337 \mathrm{v}\end{array}$} & & $329 v$ & $339 \mathrm{r}, 394 \mathrm{v}$ \\
\hline $\begin{array}{c}1384 \\
(8)\end{array}$ & $380 \mathrm{r}, 394 \mathrm{r}$ & \multicolumn{2}{|c|}{$382 v$} & \multicolumn{2}{|c|}{$\begin{array}{l}\text { 391r, 392r, 392v, } \\
\text { 393r, }\end{array}$} & & & \\
\hline
\end{tabular}


Martinelli described this type of accounting system used to reflect trading transactions in mediaeval companies as follows:

"The accounts opened to merchandise had the same nature: at first they were reported in a different book, and later in a separate section of the ledger. Accounts showing purchases and sales of merchandise for the firm or for third parties were assimilated to the so-called "personal accounts," or accounts for debts and credits: when a purchase was made the account was debited (there was an account for each purchase, and not an account for classes of merchandise); the account was further credited for sales, which were made at different times. The balance of the two sections represented the profit or the loss of the operation".... "Further, we must add the derived or income accounts, used for expenses and revenues, which often were separated to avoid confusion and to obtain more analytical records. Characteristic unilateral accounts were those for additional costs for the purchase of merchandise, which were usually recorded in separate books" (Martinelli, 1974).

Originally, the accountant chose the typical structure of accounting records for that time. The first 329 folios (spreads) were allocated for the personal accounts of debtors and creditors including the owner accounts. Folios from 330v to 400v were designed for the "Purchase and Sale of goods" accounts and the accounts for the accumulation of operational results. However, beginning in 1385 he used the pages of the book from folio $401 \mathrm{v}-402 \mathrm{r}$ up to folio $467 \mathrm{v}-468 \mathrm{r}$ for a series of personal accounts of debtors and creditors.

The feature of the General Ledger in yellow leather binding, which is also called the Libro Grande Giallo, is that the Merchandise accounts, where "Purchase and Sale of goods" information taked place, were opened for each batch of goods and were not closed until they were completely sold. In 1383, 141 accounts of this type were opened on 67 pages. However, the accounts for goods purchased in 1382, before the official presentation of the proprietorship, were placed after page 339v.

The first thing to note is that, according to F. Melis (1950, pp. 176 - 177), the first Datini proprietorship in Pisa was closed on August 19, 1386 (the day before the opening of the second proprietorship), and the personal accounts in the Ledger were still being opened in subsequent years. For this reason, in the "Yellow" book we managed to find personal accounts of debtors and creditors dated back to 1387 (459v-462r), 1403 (462v-465r), and 1406 (465v-468r).

Similarly, the "Purchase and Sale of goods" accounts, opened in 1382 (340r-342r), 1383 (331v, $332 v, 335 r(1), 344 v-375 v) 1384$ (376r-401r), continued to be used up to 1406.

Particular attention should be paid to the accounts for the accumulation of operational results, which were opened for each type of activity, separately for operating profits and operating losses. As a rule, operational results were consistently accumulated in several accounts. In our example the accounts for the operational results accumulation were transferred to another book.

This happened in 1384, when the General Ledger in the yellow book reached a significant volume of 400 folios. The bookkeeper decided to open book - Merchandises "B" (its structure is shown in Table 2, containing the "Purchase and Sale of goods" accounts and the accounts for operational results accumulation. Figure 1 shows a series of operationally accumulative accounts designed to generate the total of P1.2 "Profits of many trades". It is clearly seen in Figure 1 that the consecutive line includes four accounts from the old book and four accounts from the new one.

Table 2. The structure of the book Merchandises (Mercanzie) “B” (Prato, AS. D., №377)

\begin{tabular}{|c|c|c|}
\hline \multicolumn{2}{|c|}{ Merchandise Accounts (Purchase and Sale of goods) } \\
\hline 1384 & 1385 & 1386 \\
\hline $2 \mathrm{r}-3 \mathrm{r}, 5 \mathrm{r}-6 \mathrm{v}, 7 \mathrm{v}-10 \mathrm{r}, 11 \mathrm{v}, 13 \mathrm{r}-$ & $33 \mathrm{v}, 34 \mathrm{v}-37 \mathrm{r}, 38 \mathrm{r}-41 \mathrm{v}, 43 \mathrm{r}, 43 \mathrm{v}, 45 \mathrm{v}-46 \mathrm{v}$, & $61 \mathrm{r}, 62 \mathrm{v}-64 \mathrm{v}, 65 \mathrm{v}$, \\
$18 \mathrm{v}, 19 \mathrm{v}, 20 \mathrm{r}, 21 \mathrm{r}-28 \mathrm{r}, 29 \mathrm{v}-30 \mathrm{v}$, & $47 \mathrm{v}, 48 \mathrm{v}-50 \mathrm{v}, 52 \mathrm{v}, 53 \mathrm{r}, 55 \mathrm{r}, 56 \mathrm{v}-58 \mathrm{r}, 59 \mathrm{r}-60 \mathrm{r}$ & $66 \mathrm{v}-68 \mathrm{v}, 70 \mathrm{r}, 70 \mathrm{v}$ \\
\hline $31 \mathrm{v}, 32 \mathrm{v}$ & & \\
\hline
\end{tabular}




\begin{tabular}{|c|c|c|c|c|c|c|c|}
\hline \multirow{2}{*}{ Year } & \multicolumn{4}{|c|}{ Accounts for profits } & \multicolumn{4}{c|}{ Accounts for losses } \\
\cline { 2 - 8 } & $\mathrm{P} 1.1(6)$ & P1.2 (4) & P1.4 (17) & L1.1 (1) & L1.2 (4) & L1.3 (10) & L1.5 (3) \\
\hline 1384 & $7 \mathrm{r}, 19 \mathrm{r}, 31 \mathrm{r}$ & $3 \mathrm{v}, 17 \mathrm{v}$ & $\begin{array}{c}4 \mathrm{r}, 10 \mathrm{v}, 16 \mathrm{v}, 20 \mathrm{v}, \\
29 \mathrm{r}, 33 \mathrm{r}\end{array}$ & - & $12 \mathrm{r}, 32 \mathrm{r}$ & $\begin{array}{c}4 \mathrm{v}, 12 \mathrm{v}, \\
28 \mathrm{v}\end{array}$ & $11 \mathrm{r}$ \\
\hline 1385 & $45 \mathrm{r}, 53 \mathrm{v}$ & $44 \mathrm{r}$ & $\begin{array}{c}37 \mathrm{v}, 44 \mathrm{v}, 48 \mathrm{r}, 51 \mathrm{r}, \\
54 \mathrm{r}, 55 \mathrm{v}, 58 \mathrm{v}\end{array}$ & $47 \mathrm{r}$ & $52 \mathrm{r}, 60 \mathrm{v}$ & $\begin{array}{c}34 \mathrm{r}, 42 \mathrm{v}, \\
51 \mathrm{v}, 56 \mathrm{v}\end{array}$ & $42 \mathrm{r}$ \\
\hline 1386 & $71 \mathrm{v}$ & $70 \mathrm{v}$ & $62 \mathrm{r}, 65 \mathrm{r}, 69 \mathrm{r}, 71 \mathrm{r}$ & - & - & $\begin{array}{c}61 \mathrm{v}, 69 \mathrm{v}, \\
72 \mathrm{r}\end{array}$ & $66 \mathrm{r}$ \\
\hline
\end{tabular}

The new ledger, as well as the previous one (Prato, AS. D., №357), presents the accounts of both types that are in a form of a paragraph. For the "Purchase and Sale of goods" accounts its debit (the cost of purchase) is always placed at the top and the credit (revenue) - under the debit. The operating result (profit or loss) is recorded at the bottom of the account under its credit part. The accounts for accumulation of operating profits start with the credit; its debit is used to close the account and transfer the account balance to the account-continuation. The situation is reversed for the accounts for operating losses accumulation.
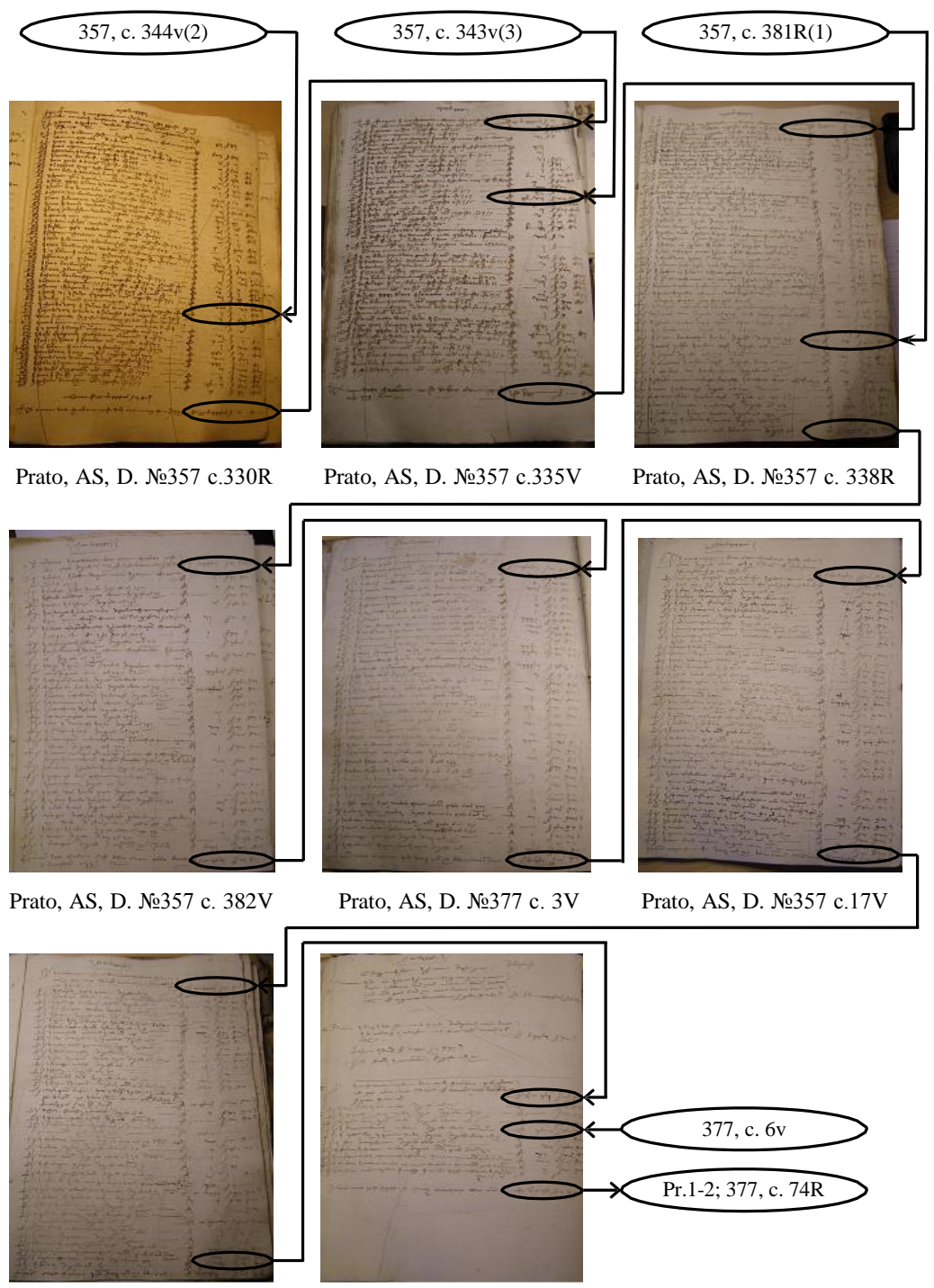

Prato, AS, D. №377 c. 3V

Prato, AS, D. №357 c.17V

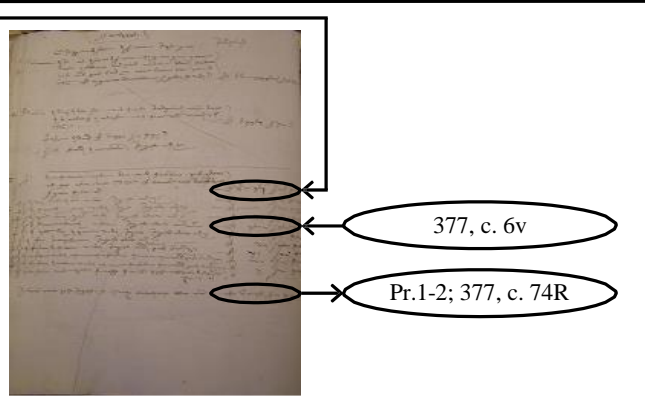

Prato, AS, D. №377 c. 44R

Prato, AS, D. №377 c. 70 V(2)

Figure 1. A series of accumulative accounts intended to prepare the total of P1.2 "Profits of many trades" 
Figure 2 shows an example of a diagram of recording and distribution the operating profit in the "Purchase and Sale of madder and Cortonese logs" account (Prato, AS. D., №357, c. 344v(1). Its photocopy is presented in Figure 3. Table 3 provides the translation of this account.

The purchase amount (f. 43 s. 1) was transferred from the Memorial of Merchandises A at c. 180. The entries in the Memorial were made as early as 1382. In addition, the expenses increased by s. 11 (for weighing and sorivano s. 5 to pay the laborers who weighed and loaded onto the boat s. 8 and for a commission to Domenico da Barbarino - s. 25).

/

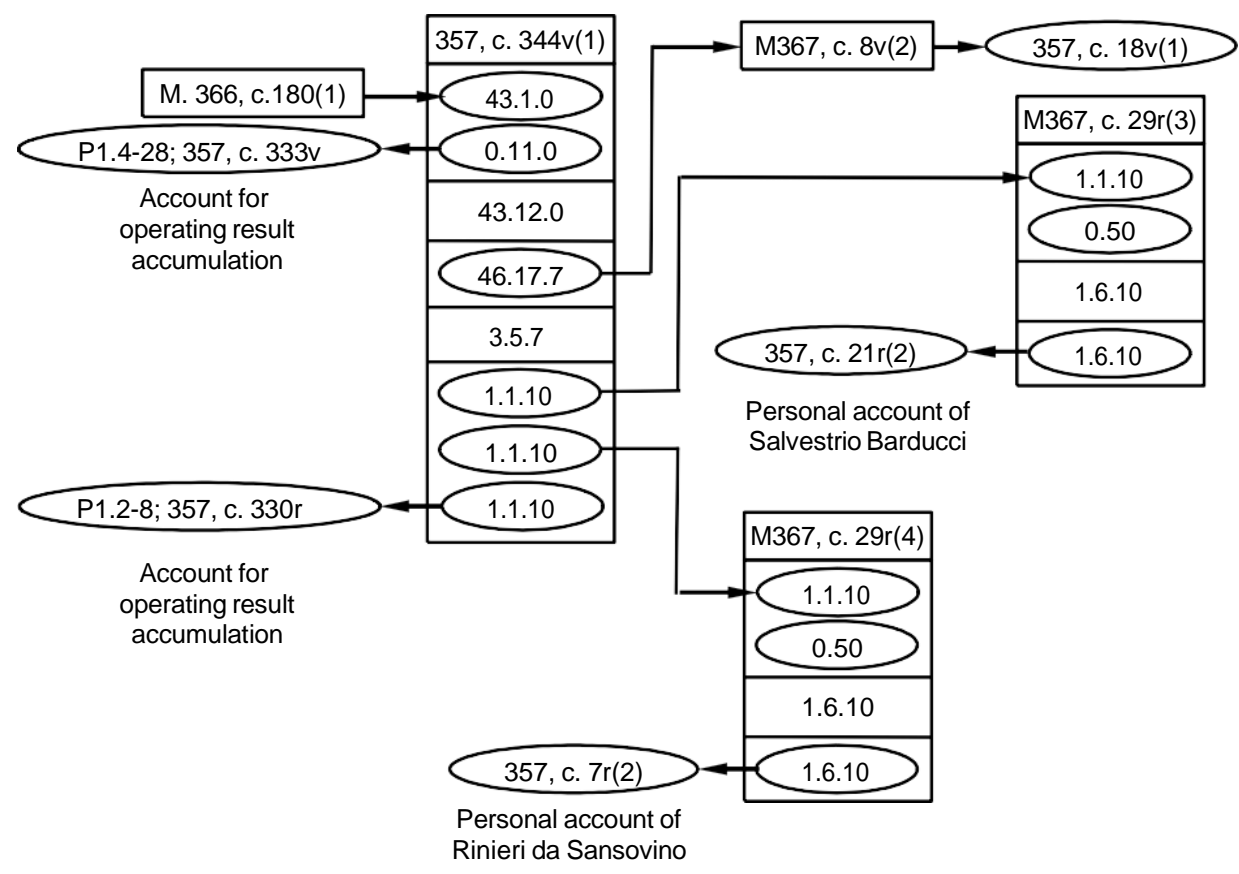

Figure 2. The diagram of recording and distributing the operating profit in the "Purchase and Sale of madder and Cortonese logs" or "Venture" accounts

In the diagram, the oval means an account in the Ledger from which (or to which) the indicator is transferred. The first identifier inside the oval is the code in the book of account according to the archives, the figures after "c." (Carta) is the sequence number of the page in the book. The additional feature, " $r$ " or " $v$ ", indicates the position of the page on the folio (front or back). The number in parentheses indicates the sequence number of the account on page. 357, c. $21 \mathrm{r}(2)$ means that the entry was made in the book numbered 357, on the front side of page 21, in the second account on the page. If the account was in the Memorial, then the Latin letter " $M$ " was added in front of the book number.

The diagrams preserve the actual presentation of the account - (the mingled or the bilateral forms). In the given example, all the accounts are represented in the mingled (paragraph) form.

The indication in the oval P1.4-28; 357, c. 333v means that the account 357, c. $333 \mathrm{v}$ is included in the line of the fourth indicator of profit formation on the first spread of the "Profit on Merchandise" account, the serial number of the account in the line is 28.

The following figures employ the same indications. The reference to Entrata e Uscita is marked correspondingly by letters "E" or "U" and the reference to the Trial Balance has the additional marks "DU" (outgoing debit) or "CU" (outgoing credit). 


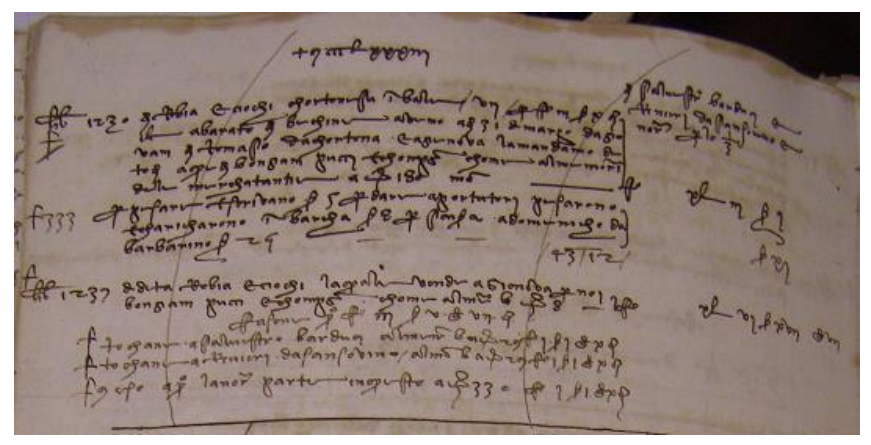

Figure 3. The "Purchase and Sale of madder and Cortonese logs" or "Venture" account (Prato, AS. D., №357, c. 344v(1)

Table 3 - The translation of Prato, AS, D. №357, c. 344v(1)

\begin{tabular}{|c|c|}
\hline \begin{tabular}{|l|c|}
+1383 & Of Salvestro Bandini and Rinieri da Sansovino and our fri \\
\end{tabular} & ads for $1 / 3$ \\
\hline \multicolumn{2}{|c|}{$\begin{array}{l}\text { Lib. } 1230 \text { of madder and Cortonese logs in } 7 \text { bales for f. } 3 \text { s. } 10 \text { a oro each } 100 \text {, bartered } \\
\text { against bechine on March } 31^{\text {st }} \text { with Giovanni di Tommaso da Cortona and we sent them on } \\
\text { the same day to Genoa to the partners of Bongianni Pucci and Co. as in the Memorial of } \\
\text { Merchandises A at c. } 180\end{array}$} \\
\hline $\begin{array}{l}333 \text { for weighing and sorivano s. } 5 \text { to pay the labourers who weighed and loaded on the boat } \\
\text { s. } 8 \text { for commission to Domenico da Barbarino s. } 25\end{array}$ & s. 11 \\
\hline \multicolumn{2}{|c|}{ f. 43 s. 12} \\
\hline $\begin{array}{l}\text { Lb. } 1237 \text { of the aforementioned madder and logs which were sold in Genoa for us by } \\
\text { Bongiani Pucci and Co. as in the Memorial B at c. } 8\end{array}$ & f. 46 s. 17 d. 7 \\
\hline \multicolumn{2}{|l|}{ The profit was f. $3 \mathrm{~s} .5 \mathrm{~d} .7$ of gold } \\
\hline Salvestrio Barducci is entitled to, as in the Memorial B at c. 29 & f. 1 s. 1 d. 10 \\
\hline Rinieri da Sansovino is entitled to, as in the Memorial B at c. 29 & f. 1 s. 1 d. 10 \\
\hline And our part was put in this book at c. 330 & f. $1 \mathrm{~s} .1 \mathrm{~d} .10$ \\
\hline
\end{tabular}

The purchase amount (f. 43 s. 12) was transferred from the Memorial A at c. 180. The entries in the Memorial were made as early as 1382. In addition, the expenses increased by s. 11 (for weighing and sorivano s. 5, to pay the laborers who weighed and loaded on the boat s. 8, for commission to Domenico da Barbarino - s. 25).

The mentioned sum was transferred to the accumulative account of Prato, AS. D., No357, c. 333v. This account is the first one in the consecutive line P1.4 (for many expenses on trades from us and our friends), consisting of 28 accounts: 11 accounts are kept in the first book and 17 accounts - in the second one. The identification code of the account P1.4-28 includes the account number from the final total. Accordingly, the account, on which the total is generated (Prato, AS. D., №377, c. 71r), has the code - P1.4-28.

The debit total of the account (Prato, AS, D., No. 357, pp. 344v (1) equaled f .43 s.12.

The amount of revenue was determined in the Memorial in the account of Prato, AS. D., №367, c. $8 \mathrm{v}(2)$ in the sum of f. 46 s. 17 d. 7. It was recorded in the customer account Bongiani Pucci and Co (Prato, AS. D., №357, c. 18v) and in the credit of the "Purchase and Sale of goods" account.

The profit on sale made f. 3 s. 5 d. 7.

Taking into account that the transaction was carried out with counterparts Salvestrio Barducci and Rinieri da Sansovino, the profit was divided into three parts, f. $1 \mathrm{s.} 1 \mathrm{~d}$. 10 each. The amounts assigned for partners were transferred to the Memorial Prato, AS. D., №367 on page 29r, where a separate account was opened for each of them. The final amount (f. $1 \mathrm{~s} .1 \mathrm{~d}$. 10) calculated for each partner was credited to their personal accounts.

Concerning the share of the profit belonging to Francesco Datini (f.1 s.1d.10), it was brought forward to the accumulating profit account Prato, AS. D., №357, c. 330r (Figure 2 represents it as the first one from above). The figure shows the entry standing for the transfer of the profit share. 
The early system of determining the financial result in the First Datini's proprietorship seems almost completed. The proof is three consecutive lines of accounts for accumulation of operating profits and four - for accumulation of operating losses. Thus, all the necessary conditions for the production of the account for Profits and Losses were established. However, during the closure of the First proprietorship such an account was not created. The first Profits and Losses account appeared in 1393 while the Second proprietorship was closing (F. Melis claimed that the closing date of the proprietorship was June 30, 1392, the day before the opening of the first company in Pisa).

Meanwhile the last three folios of the book Merchandises "B” (Prato, AS, D. №377) include the account for Profits and Losses dating to 1406. The account contains not only the results calculated on the accounts of the consecutive lines of the accounts for the accumulation of operating results, but on a variety of personal operational accounts, which were calculated after 1386. This indicates that the "Purchase and Sale of goods" accounts did not close until the complete sale of the batch of goods. This is the reason why the new personal accounts of customers to buy the leftover goods were opened in the General Ledger.

In order to understand the situation, there are some examples shown in Figure 4.

To begin with let us consider an example in which all business transactions are dated 1386 . The left part of figure 3 is mainly occupied by "Purchase and Sale of of Domaschino sugar in Pisa on behalf of us and Bongianni Pucci and Co. of Florence for Francesco himself" account.

The cost of the sugar purchase from Bongianni Pucci and Co. amounted to f. 905 d. 9 (the contra account in Memoriale "C" - Prato, AS, D. №. 368, p. 54v(6). Additional expenses recognized are shown by the 20th indicator on the account (Prato, AS, D. № 377, c. 71r). The account in question, placed in the Mercanzie book, is the first account in the line P1-4 of 27 accounts forming the fourth indicator on the first folio of "Profit on Merchandise" account (a forerunner of the profits and losses account). The entry says: "Profit on Merchandise must have ... for many expenses on trades from us and our friends put in this book at c. 71 expenses gave f. 8408 s. 12 d. 10 a oro". We should note that the accounts in the lines are numbered in the reverse order - from "Profit on Merchandise" account. This is due to the fact that certain pages in the medieval books may be lost. In this case, the numbering in direct sequence may lose its point.

The total purchase cost was f. 923 s. 17 d. 3 a oro.

All the sales were made in 1386:

- Brardo di Giovanni Berettini - amounting to f. 58 s. 6 d. 3;

- Aldobrandino Cianpoli - amounting to f. 124 s. - d. 6;

- Dosso Spini - amounting to f. - s. 10 d. 10 (the entry in Entrata e Uscita and the sum was set by the authors);

- Geri di Michele and Co. - amounting to f. 166 s. 4 d. 6;

- Bartolomeo da Campiglia - amounting to f. 79 s. 6;

- 8 cases Francesco di Marco sold on our behalf in Pisa - amounting to f. 411 s. 17 d. 2;

- Francesco di Marco himself - amounting to f. 48 s. 14 d. 8

Total sum f. 888 s. 19 d. 11 a oro, which is f. 34 s. 16 d. 1 a oro less than the cost of acquisition. 


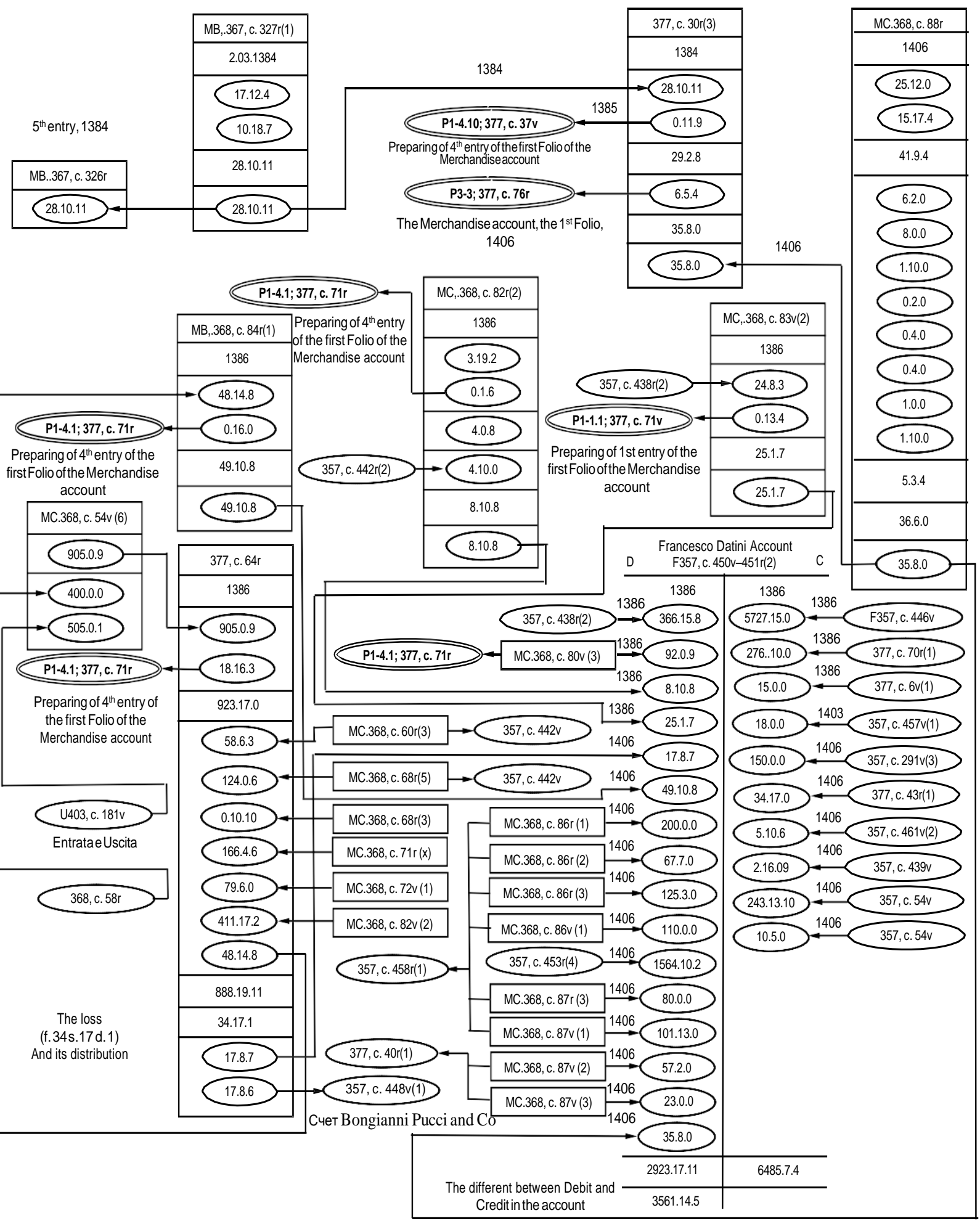

Figure 4 - Diagram of the closing accounts in F. Datini's first proprietorship in Pisa in 1406 
The loss is apportioned equally between F. Datini (f. 17 s. 8 d. 7 a oro - the account entry says: "And he must give on December 14th f. 17 s. 8 d. 7 for his half of 15 cases of Domaschino sugar bought by him and Bongianni in common as in the Book of merchandises B at c. 64") and the partners in the transaction Bongianni Pucci and Co (f. 17 s. 8 d. 6 a oro).

What is noticeable here, that F. Datini's share in the loss was not charged to "Profit on Merchandise” account, but to F. Datini’s personal account (Prato, AS, № 357, c. 450v - 451r). The rest of the accounting procedure is typical.

Table 4 - The translation of Prato, AS, D. №377, c. 64r

\begin{tabular}{|c|c|}
\hline \multicolumn{2}{|l|}{1386} \\
\hline $\begin{array}{l}\text { Purchase of Domaschino sugar in Pisa on behalf of us and Bongianni Pucci and Co. of } \\
\text { Florence for Francesco himself }\end{array}$ & \\
\hline $\begin{array}{l}\text { Lbs. } 1352 \text { of Domaschino sugar for } \mathrm{f} .27 \text { for } 100 \text { we purchased from Gieri di Michele } \\
\text { and Co. and the total sum can be seen in the Memorial C at c. } 54\end{array}$ & f. 905 d. 9 \\
\hline $\begin{array}{l}\text { For commissions on this purchase f. } 1 \mathrm{~s} \text {. } 5 \text {, for bringing all home f. } 1 \text {, to the weighed } \\
\text { and for loss and to the scrivener s. } 23 \text { for } 15 \text { new and old cases, f. } 5 \mathrm{~s} \text {. } 39 \text { for } 3 \text { some of } \\
\text { straw s. } 15 \text { for putting into the cases to the binders and to the porters for helping moving } \\
\text { from a place to another f. } 1 \mathrm{~s} .8 \text {, for bringing home the empty cases s. } 5 \text {, for commissions } \\
\text { on } 6 \text { cases we sold s. } 30 \text {, for our commission at } 1 \text { per } 100 \text { of the purchase f. } 9 \text {, the sum } \\
\text { f. } 17 \text { s. } 6 \text { d. } 5 \text { - at s. } 69 \text { for f. } 1 \text { they are }\end{array}$ & f. 18 s. 16 d. 3 \\
\hline \multicolumn{2}{|l|}{ The total sum is f. 923 s. 17 a oro } \\
\hline $\begin{array}{l}\text { Lbs. } 214 \text { of the said broken sugar to Brardo di Giovanni Berettini at f. } 271 / 4 \text { for 100, as } \\
\text { in the Memorial C at c. } 60\end{array}$ & f. 58 s. 6 d. 3 \\
\hline $\begin{array}{l}\text { Lbs. } 451 \text { of the said broken and unbroken in } 2 \text { cases at f. } 271 / 2 \text { to Aldobrandino Cianpoli } \\
\text { as in the Memorial C at c. } 68\end{array}$ & f. 124 s. - d. 6 \\
\hline $\begin{array}{l}\text { Lbs. } 2 \text { of the said sugar sold to Dosso Spini as in Entrata B at c. xxx [c. } 75 r \text {, established } \\
\text { by the authors] }\end{array}$ & f. - s. 10 d. 10 \\
\hline $\begin{array}{l}\text { Lbs. } 499 \text { of the said unbroken sugar in } 3 \text { cases for f. } 271 / 3 \text { for } 100 \text { to Geri di Michele } \\
\text { and Co. as in the Memorial C at c. } 71\end{array}$ & f. 166 s. 4 d. 6 \\
\hline $\begin{array}{l}\text { Lbs. } 291 \text { of the said broken sugar in } 1 \text { case to Bartolomeo da Campiglia apothecary at } \\
\text { f. } 271 / 4 \text { for } 100 \text { as in the Memorial C at c. } 72\end{array}$ & f. 79 s. 6 \\
\hline $\begin{array}{l}\text { Lbs. } 1607 \frac{1}{2} \text { of the said sugar in } 8 \text { cases Francesco di Marco sold on our behalf in Pisa } \\
\text { and he got net as in the Memorial C at c. } 82\end{array}$ & f. 411 s. 17 d. 2 \\
\hline $\begin{array}{l}\text { Lbs. } 181 \frac{1}{2} \text { of the said sugar at f. } 27 \text { for } 100 \text { to Francesco di Marco himself as in the } \\
\text { Memorial C at c. } 83\end{array}$ & f. 48 s. 14 d. 8 \\
\hline \multicolumn{2}{|l|}{ Lbs. 3345 Total sum f. 888 s. 19 d. 11 a oro } \\
\hline \multicolumn{2}{|l|}{ The loss is f. 34 s. 16 d. 1 a oro } \\
\hline $\begin{array}{l}\text { To Bongianni Pucci and Co. for their half as in the Yellow Book B at c. } 448 \text { they must } \\
\text { give }\end{array}$ & f. 17 s. 8 d. 6 a oro \\
\hline $\begin{array}{l}\text { To Francesco di Marco himself for his half as in the Yellow Book B at c. 450, } \\
\text { Francesco must give }\end{array}$ & f. 17 s. 8 d. 7 a oro \\
\hline
\end{tabular}

Now let us look at the example when "Purchase and Sale of goods" account was opened in 1384, and the final operations were performed in 1406. At the top of the diagram (Figure 3) there is "Purchase and Sale of mutton leather and mutton skin of Catalonia in Pisa on our (of Florence) behalf" account, which is third in the book of Merchandises (Mercanzie) "B" (Prato, AS. D., No. 377), on p. 30r (translation is given in table 5). This entry was made on March 2, 1384 on the basis of the entry in Memoriale “B” (Prato, AS, D. №. 367, p. 327r (1). 
Table 5 - The translation of Prato, AS, D. №377, c. 30r(3)

\begin{tabular}{|l|l|}
\hline 1384 & \\
\hline $\begin{array}{l}\text { Purchase of mutton leather and mutton skin of Catalonia in Pisa on our (of Florence) } \\
\text { behalf }\end{array}$ & \\
\hline Lbs. 418 net of mutton skins in 2 bales at (?) 14 s. 15 for 100 & \\
\hline $\begin{array}{l}\text { Lbs. } 225 \text { net of mutton leather in bale I for s. } 17 \text { for } 100 \text { we bought from Piero } \\
\text { Carbonellieri, the sum is as the Memorial B at c. } 327\end{array}$ & f. 28 s. 10 d. 11 \\
\hline $\begin{array}{l}\text { For weighing and expenses for the scrivener and for the aportatori s. } 7 \text {, for the binding } \\
\text { s. } 6 \text {, for strings s. } 6 \text {, for expenses of tratta and sindaco s. 3, for commissions at d. } 2 \text { for s. } \\
18 \text { d. } 6, \text { the sum is }\end{array}$ & s. 11 d. 9 \\
\hline $\begin{array}{l}|c| \\
\text { And they must give f. } 6 \text { s. } 5 \text { d. } 4 \text { a oro for profit on the aforementioned muttons as in this } \\
\text { book at c. } 76 \text { at the account Profit on Merchandise must have }\end{array}$ & f. 6 s. 5 d. 4 \\
\hline \multicolumn{1}{|c|}{35.8 .0} & \\
\hline $\begin{array}{l}\text { Bales } 3 \text { lbs. } 610 \text { net Francesco di Marco himself sold and we get net of expenses, } \\
\text { when they will be collected, as in the Memorial C at c. } 88\end{array}$ & f. 35 s. 8 a oro \\
\hline
\end{tabular}

Table 6 - The translation of Prato, AS, D. №367, c. 327r(1)

\begin{tabular}{|l|l|}
\hline March 2nd 1384 & \\
\hline $\begin{array}{l}\text { Piero Carbonelli must have on this day, on his behalf Antonio Macheroni withdraws for } \\
\text { us }\end{array}$ & \\
\hline $\begin{array}{l}\text { Muttonskins of Catalonia } 2 \text { bales or lbs. } 422 \text { tare lbs. } 4 \text { net lbs. } 418 \text { for s. } 14 \text { s. } 15 \text { [sic!] } \\
\text { for } 100 \text { a oro }\end{array}$ & f. 17 s. 12 d. 4 \\
\hline Muttonskins of Catalonia 1 bale or lbs. 228 tare lbs. 3 and net lbs. 225 for s. 27 fir 100 & f. 10 s. 18 d. 7 \\
\hline $\begin{array}{l}\text { He had on the aforementioned day f. } 28 \text { s. } 10 \text { d. } 11 \text { a oro we gave on his behalf to Messer } \\
\text { Bandino Bonconti and Messer Nicolò di Pangnozo and Co. gives him on our behalf as in } \\
\text { this book at c. } 326 \text { Messer Nicolò must have }\end{array}$ & \\
\hline
\end{tabular}

Both accounts are maintained in columnar form. The account in Memoriale records the cost of acquisition (f. $28 \mathrm{~s} .10 \mathrm{~d}$. 11), which is transferred to the credit of the account of suppliers Messer Nicholo di Pangnozzo and Simone di Ser Piero and Co. (Prato, AS, D. No. 367, p. 327r), as the record shows:" And they must have on March 2nd f. 28 s. 10 d. 11 a oro of which Messere Banduccio Bonconti gave it to us. 327". And, as was already mentioned, the entry was made to the debit side of account "Purchase and Sale of mutton leather and mutton skin of Catalonia in Pisa on our (of Florence) behalf".

On the last account, only in 1385 the cost of services rendered was taken into account: "For weighing and expenses for the scrivener and for the aportatori s. 7, for the binding s. 6, for strings s. 6 , for expenses of tratta and sindaco s. 3, for commissions at d. 2 for s. 18 d. 6, the sum is s. 11 d. 9".

The given sum is shown by the 10 th indicator on the account Prato, AS, D. No. 377, p. 37v. This account, placed in Mercanzie book, is the $18^{\text {th }}$ account in the dynamic line of 27 accounts, forming the fourth indicator on the first folio of "Profit on Merchandise" account (prototype of Profits and Losses account). The entry says: "Profit on Merchandise must have ... for many expenses on trades from us and our friends put in this book at c. 71 expenses gave f. 8408 s. 12 d. 10 a oro".

The total value of the consignment was f. 29 s. 2 d. 8 .

The described consignment of goods was not subject to sale until 1406. On May 28, 1406 in Memoriale "C" (opened in 1385), there appeared account Prato, AS, D. No. 368, c. 88r (translation is given in table 7). Besides, the account is the last one in this Memoriale. The first entry in the account indicates that the consignment of goods purchased in 1384 was sold 12 years later personally by Francesco di Marco. The real sales proceeds, received personally by Datini, were f. 41 s. 8 d. 4 a oro. 
Table 7 - The translation of Prato, AS, D. №368, c. 88r

\begin{tabular}{|c|c|}
\hline \multirow[b]{2}{*}{$\begin{array}{l}1406 \\
\text { Francesco di Marco himself must give on May 28th } 1406 \text { for value of bales } 2 \text { of } \\
\text { mutton skins of Catalonia and } 1 \text { bale of mutton leather of Catalonia he sold on our } \\
\text { behalf, he had received them until March 7th } 1384 \text { as in the Book of Niccolo } \\
\text { dell'Ammannato: }\end{array}$} & \\
\hline & \\
\hline $\begin{array}{l}2 \text { bales of mutton skins of Catalonia to Jacopo di Piero saddler on March 8th } 1384 \\
\text { lbs. } 394 \text { net at f. } 5 \mathrm{~s} .10 \text { for } 100\end{array}$ & f. 25 s. 12 a oro \\
\hline $\begin{array}{l}1 \text { bale of mutton leather of Catalonia to Niccolò di Giovanni di Neri on March 17th } \\
1384 \text { lbs. } 216 \text { net at f. } 7 \text { s. } 6 \text { d. } 8 \text { for } 100\end{array}$ & f. $15 \mathrm{s.} 17$ d. 4 a oro \\
\hline \multicolumn{2}{|l|}{ The sum is f. 41 s. 8 d. 4 a oro } \\
\hline \multicolumn{2}{|l|}{ We subtract, for expenses made to the aforementioned 3 bales, as here below: } \\
\hline For shipment and transit fees from Pisa to Florence for lbs. 650 at s. 18 for 100 & lb. 6 s. 2 \\
\hline For gabbles of Florence & lb. 8 \\
\hline For commission on sale & lb. 1 s. 10 \\
\hline For weighing at the veditori & Lb. - s. 2 \\
\hline For weighing at selling to the Commune & Lb. - s. 4 \\
\hline For shipping to purchasers & Lb. - s. 4 \\
\hline For loss on exchange d. 6 for f. 1 & Lb. 1 \\
\hline For their commission at 1 per 100 & lb. 1 s. 10 \\
\hline Total sum of the expenses lb. 18 s. 12 at s. 7 for f. 1 they are & f. 5 s. 3 d. 4 \\
\hline $\begin{array}{l}\text { What remains net is f. } 36 \text { s. } 15 \text { a oro, they are worth in Pisa at } 2 \frac{1}{2} \\
\text { per } 100\end{array}$ & f. 35 s. 8 a oro \\
\hline Put at the Yellow Book B at c. 450 & \\
\hline
\end{tabular}

Further (table 7), the indicator of accounting revenue (f. 35 s. 8 a oro) is formed, which is shown simultaneously on the account of 1384 (Purchase of mutton leather and mutton skin of Catalonia in Pisa on our (of Florence) behalf - Prato, AS. D., №377, c. 30r(3)) and in the debit side of Francesco di Marco Datini's personal account (Prato, AS, D. No. 357, p. 450v-451r). The account entry says: "And he must give on this day f. 35 s. 8 d'oro for the value of 3 bales of mutton skins of Catalonia sold on our behalf until May 1384 as in the Memorial C at c. 88".

There are explanations for this.

From the text of the translation of the account only the reference to Francesco di Marco's account is seen, and the reference to the account in Memoriale " $\mathrm{C}$ ", at first glance, is missing. In medieval books, as a rule, the address of the corresponding entry was shown only in figures to the left of the main entry without indicating the register in which the account was located. In the given example, to the left of the entry with the sum of f. 35 s. 8 a oro number " 30 " was filled in, which indicates the account Prato, AS. D., No. 377, p. 30r(3).

It is understandable why this sum is charged to the debit side of the company's owner account. Firstly, nowhere is it indicated that F. Datini entered the received sum in Entrata e Uscita book. It is logical that if the owner withdrew the given sum from circulation, the amount of the invested capital should be reduced. Reduction of accounting revenue from the one amounting to f. $5 \mathrm{s.} 3$ d. 4 is also explainable. This was the cost of additional services that F. Datini did not consider necessary to show both on "Profit on Merchandise" account (a prototype of the Profits and Losses account) and to reduce the size of his contribution.

The identified sum of operating profit for this consignment of goods (f. $6 \mathrm{~s} .5 \mathrm{~d}$. 4) is transferred to the third position of the third folio "Profit on Merchandise" account (And they must give f. 6 s. 5 d. 4 $a$ oro for profit on the aforementioned muttons as in this book at c. 76 at the account "Profit on Merchandise must have"). 
The given example confirmed our assumption that in Francesco Datini's First Proprietorship in Pisa (as well as in the second one, opened in 1386 during the period of the first proprietorship' activity) the accounts were not closed until the complete sale of consignments of goods entered in "Purchase and Sale of goods" accounts. We have identified many similar examples when accounts were closed in the second half of 1386 and during the period of 1387-1406. Francesco di Marco was the sole owner of the proprietorship. For this reason, he was not pressured by the requirement of periodical withdrawal and distribution of profits among the partners. Moreover, starting in 1387, he withdrew cash without registering it in Entrata e Uscita. At the same time, he debited his personal account, thereby reducing his share in the proprietorship. He wrote off some unsold goods as a loss.

Only in 1406, six years after the termination of all the companies opened with his participation in Pisa since 1392, after the closing all Merchandise accounts, the accountant prepared "Profit on Merchandise" account (Figure 5).

The account occupied six consecutive pages at the end of Mercanzie book (Prato, AS, D. № 377, p. $73 \mathrm{v}-76 \mathrm{r}$ ). Each pair of pages represented debit and credit. The exceptional difference of this account from other accounts of this type is that each page (debit and credit) began with the same words: "Profit on Merchandise", that is, "Profit on Merchandise must give" or "Profit on Merchandise must have". Each folio was balanced and the balance of account (the difference between the total of debit and credit) was transferred to the credit of the next pair of accounts. "Profit on Merchandise" account reflected both the results of operating profits and operating losses accumulated on the dynamic line accounts, as well as individual results revealed on "Purchase and Sale of goods" accounts.

As a rule, early accounts were named according to the first debit and credit entries of accounts. At the same time, the entries on "Profit on Merchandise" accounts contained indicators that not only characterized trading operations, but were related to other types of activity. In our opinion, the name Profits and Losses account is more appropriate to such accounts.

Further narration is devoted to the development of the "Purchase and Sale of goods" accounts. In this case we should agree with R. de Roover's later conclusion $(1956,115)$ that "partnership is perhaps the most important, since it led to the recognition of the firm as an entity distinct from the owners". It was during the transition from individual proprietorships to companies when the accounting was reoriented to the precise calculation of the financial result and its distribution among the owners. In our opinion, it was the first time when the accountant reflected the mechanism for identifying the operating result on the purchase and sale of goods, which was not previously described either in Luca Pacioli's Treatise or in the subsequent literary sources. This refers to the batches of goods, over which it was necessary to calculate the operational result (at the end of the reporting period), and the remaining goods that were not sold. 


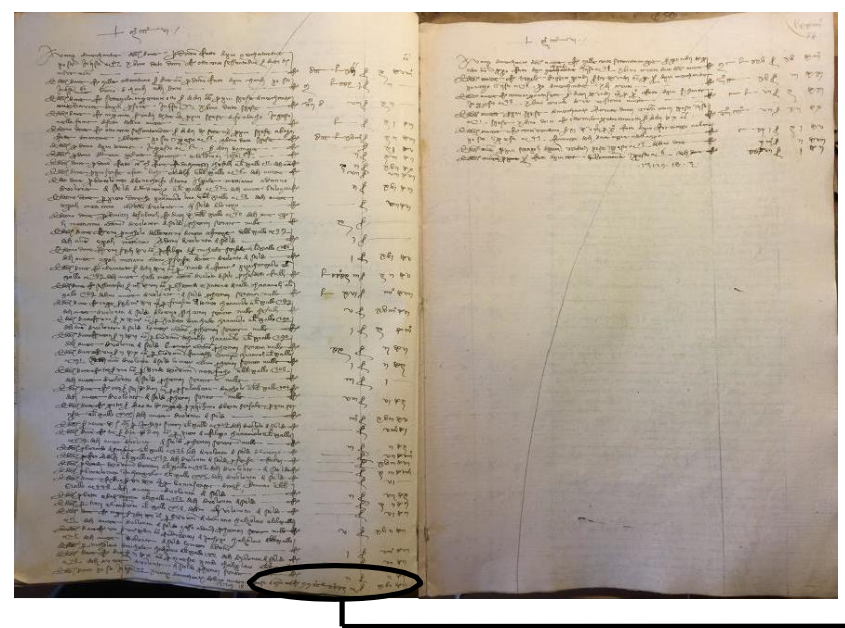

Prato, AS, D. №377, c. 73v-74r

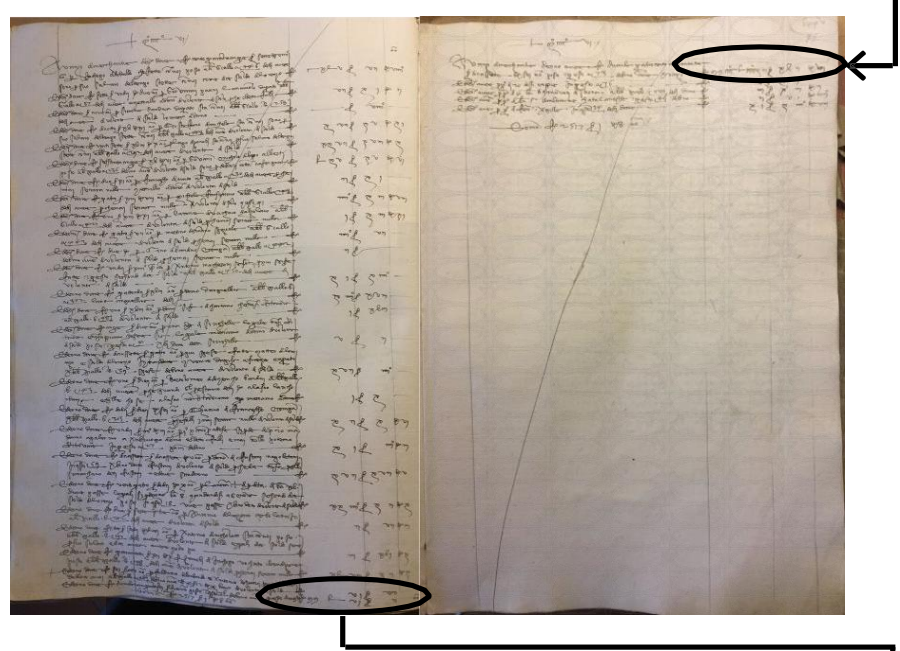

Prato, AS, D. №377, c. 74v-75r

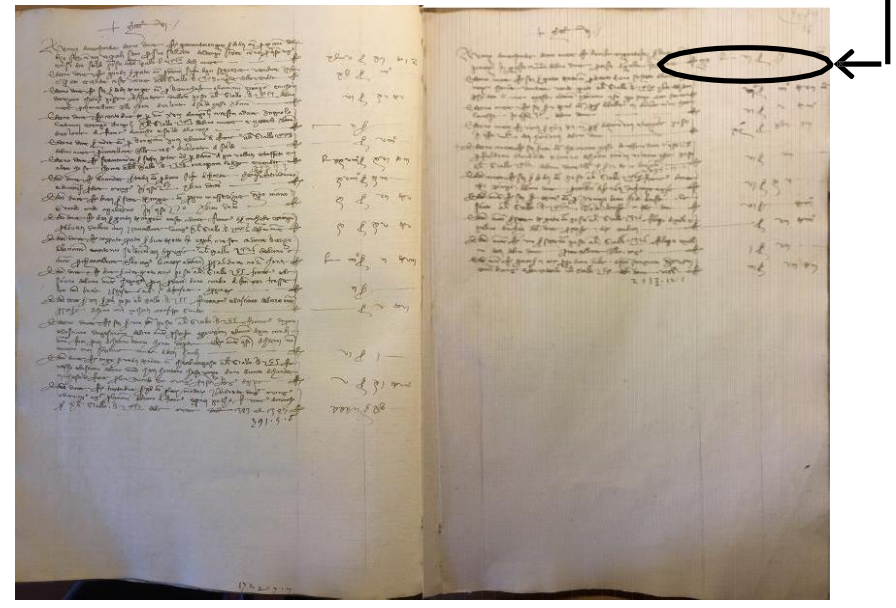

Prato, AS, D. №377, c. 75v-76r

Figure 5. Photocopies of accounts included in "Profit on Merchandise" account, F. Datini's first proprietorship in Pisa (1383-1406) 
This paper has examined an example of the "Purchase and Sale of goods" accounts application, which indicates the early practice in the companies of F. Datini. The paper provides an opportunity to calculate an accurate operating result in those cases when the company closes and the consignments of goods are not completely sold.

\section{CONCLUSION}

The main contributions of this paper lie in its revelation of the fact that, the accounting system of Francesco Datini's first proprietorship in Pisa (1383-1406) had a highly developed system of determining the financial result because of a well-executed accounts including the Merchandise ("Purchase and Sale of Goods") account and accounts for accumulating the financial result. The first group of accounts was opened for each batch of goods sold. This group revealed the operational financial result after the sale of the batch of goods was completed. The financial result from the Merchandise account was transferred to the accounts for accumulating the financial result. Consequently, all the necessary conditions for the preparation of the account "Profit on Merchandise" ("Profit on merchandise" account, a forerunner of the Profits and Losses account) were systematically created in that accounting system. In the first proprietorship, the profit was not determined until 1406. From the middle of 1386 new purchases in the first proprietorship were not conducted and new Merchandise ("Purchase and Sale of Goods") accounts were not opened, but, personal debtor accounts

- the buyers of earlier purchased goods - were regularly opened.

The authors hope that this paper focuses attention on the importance of further archival research in the Datini archive. 


\section{REFERENCES}

Antonelli, V., and Sargiacomo, M. (2015). Alberto Ceccherelli (1885-1958): Pioneer in the history of accounting practice and leader in international dissemination. Accounting History Review 25 (2): 121-144. doi:10.1080/21552851.2015.1046890

Bensa, E. (1923). Francesco di Marco Datini: discorso detto nell'Aula maggiore del Comune di Prato il di 21 agosto 1910. - Genova, ARTI GRAFICHE CAIMO \& C.

Bensa, E. (1925). Le forme primitive della polizza di carico : ricerche storiche con documenti inediti / Enrico Bensa. - Genova: Caimo.

Bensa, E. (1928). Francesco di Marco da Prato. Notizie, e documenti sulla mercatura italiana del secolo XIV, Treves, Milano.

Besta, F. (1909). La Ragioneria, 2nd Edition (In 3 Volumes), Facsimile Reprint, 2007, Rome: Rirea.

Carradori, A. (1896) Francesco di Marco Datini, mercante pratese del sec. XIV, Prato.

Ceccherelli, A. (1913). I libri di mercatura della Banca Medici e l'applicazione della partita doppia a Firenze nel secolo decimoquarto. Firenze: Bemporad.

Ceccherelli, A. (1914a). "Le funzioni contabili e giuridiche del bilancio delle società medievali." Rivista Italiana di Ragioneria 14 (8): 371-378.

Ceccherelli, A. (1914b). "Le funzioni contabili e giuridiche del bilancio delle società medievali (Continuazione e fine). " Rivista Italiana di Ragioneria 14 (10): 436-44.

Ceccherelli, A. (1939). l linguaggio dei bilanci. Formazione e interpretazione dei bilanci commerciali. Firenze: Le Monnier.

Cecchi, A.E. (2004) L'Archivio di Francesco di Marco Datini. Fondaco di Avignone. Inventario, Roma 2004

Corsani G. (1922) Ifondaci e i banchi di un mercante pratese del Trecento. Contributo alla storia della ragioneria e del commercio. Da lettere e documenti inediti, La Tipografica, Prato.

De Roover, R. (1937) Aux origines d'une technique intellectuelle: La formation et expansion de la comptabilite' a partie double. Annales D'Histoire E' conomique Et Sociale 9: 171-193, 270-298.

De Roover, R. (1956). The development of accounting prior to Luca Pacioli according to the accountbooks of Medieval merchants / R. de. Roover // Littleton A.C., Yamey B.S. Studies in the History of Accounting. London: 114-174.

Kuter, M., Gurskaya, M., Aleinikov, D. (2020), The Early Practice of Analytical Balances Formation in F. Datini's Companies in Avignon / Springer Nature Switzerland AG 2020 T. Antipova (Ed.): ICIS 2019, LNNS 78, pp. 91-102, https://doi.org/10.1007/978-3-030-22493-6_10.

Kuter, M., Gurskaya, M., Sidiropulo, O. (2013). The Genoese Commune Massari's Ledger of 1340: The First Computer Modeling Experience and Its Results. Journal of Modern Accounting and Auditing, Vol. 9, No. 2: 212-229.

Lee, G.A. (1973). The Development of Italian Bookkeeping 1211-1300. Abacus, 9 (2).

Lee, G.A. (1977) The coming of age of double entry: the Giovanni Farolfi ledger of 1299-1300, The Accountings Historians Journal, 4 (2), 79-95.

Littleton, A.C. (1966). Accounting evolution to 1900 / A.C. Littleton. - N.Y.: Russel\&Russel.

Livi G. (1910), Dall'Archivio di Francesco Datini mercante pratese, F. Lumachi, Firenze.

Martinelli A. (1974). The Origination and Evolution of Double Entry Bookkeeping to 1440. ProQuest Dissertations \& Theses Global pg. n/a.

Melis, F. (1950). Storia della Ragioneria (Bologna: Cesare Zuffi, 1950). 872 p.

Melis, F. (1954). L'archivio di un mercante e banchiere trecentesco: Francesco di Marco Datini da Prato, in "Moneta e Credito", VII.

Melis, F. (1962) Aspetti della vita economica medievale (studi nell'archivio Datini di Prato), Siena: Monte dei Paschi di Siena.

Melis, F. (1972). Documenti per la storia economica dei secoli XIII-XVI, Leo S. Olschki, Firenze, $752 \mathrm{p}$. 
Nicastro, S. (1914). L’Archivio di Francesco di Francesco di Marco Datini in Prato, Rocca S. Casciano, L. Cappelli.

Nigro, G. ed. (2010): Francesco di Marco Datini: The Man, The Merchant. Florence: Firenze University Press-Fondazione Istituto Internazionale di Storia Economica "F. Datini".

Origo, I. (1957). The Merchant of Prato, Francesco di Marco Datini, London, J. Cape.

Sargiacomo, M., Servalli, S. and Andrei, P. (2012). Fabio Besta: Accounting Thinker and Accounting History Pioneer. Accounting History Review 22 (3): 249-267.

Sangster, A. (2016). The genesis of double entry bookkeeping. The Accounting Review, 91(1), 299315.

Zerbi, T. (1936) Il Mastro a Partita Doppia di. Un’ Azienda Mercantile del Trecento. Como: E. Cavalieri.

Zerbi, T. (1952). Le Origini della partita dopia: Gestioni aziendali e situazioni di mercato nei secoli XIV e XV (Milan: Marzorati). 